\title{
INTRODUCTION
}

\section{Life and Works}

Almost all our information about Phaedrus, the Roman fabulist of the period of Augustus and Tiberius, is derived from his work itself, some of it directly, some of it by deduction. Outside that there is only one contribution, but it is an important one. It comes from the only surviving manuscript of Phaedrus, the Codex Pithoeanus (ninth century A.D.), which entitles the collection Phaedri, Augusti liberti, fabularum aesopiarum libri [The Books of Aesopic Fables by Phaedrus, the Freedman of Augustus]. That is to say, he was a slave in the household of Augustus and at some point was granted his freedom by the emperor. This is nowhere stated in the poems, although the fact of his having been a slave is supported by his expression of admiration for the figure of Aesop, the traditional originator of the genre of fable:

The Athenians set up a statue to Aesop,

Thereby placing a slave on a permanent pedestal

To the end that all should openly acknowledge

That glory is granted to greatness, not to birth.

$$
(2,9,1-4)
$$

More can be elicited from the poems themselves. We can know or deduce:

- That he was born in Pieria (the traditional home of the Muses) in Thessaly, which was at that time part of a Roman province.

- That he was possibly the son of a schoolteacher:

$$
\text { Why, even I- }
$$

Born on the slopes of Pieria (the place

Where Mnemosyne was nine times made a mother

By Jove, the sire of the sisterhood of singers),

Practically, I promise, in the precincts of a school,

$$
\text { (3, Prologue, 18-21) }
$$

- That he came, or was brought, to Italy, probably when quite young. In the following lines the maxim quoted comes from one of the tragedies of Ennius, the father of Latin poetry, a work that may well have been part of a Roman education: 
I intend to remember a maxim that I read

As a boy: "For a man of humble birth

It is not proper to protest in public."

(3, Epilogue, 44-46)

- That he suffered some sort of persecution at the hands of Sejanus, Tiberius' all-powerful minister:

Though some [of my fables] have got me into terrible trouble.

If my accuser, my judge, and my jury

Had been any other than simply Sejanus,

I'd have openly acknowledged my evident errors.

(3, Prologue, 45-48)

This passage also helps us with the dating: Sejanus died in A.D. 31, and thus Book 3 was evidently published after that date.

- That he was unpopular in certain intellectual circles, presumably because he was a foreigner by birth, an ex-slave, and successful:

\section{If malign critics}

Want to find fault, I'm quite indifferent-

They can criticize me to their hearts' content,

So long as they can't compete in my craft.

(4, Prologue, 19-22)

The reader will find a number of other expressions of the same sentiment.

- That he died in old age. This is surely a legitimate deduction from the last fable of his last book:

A dog who had once been dauntless and dashing

Against all wild game, and had given his master

Constant service and satisfaction,

Began to grow feeble from the burden of the years.

One day, doing battle with a bristling boar,

He had got it by the ear, but it easily escaped

By twisting away from the decayed teeth. 
The hunter, deprived of his expected prey,

Scolded his hound, who then countered:

"It's strength, not spirit, that's deserted me, master.

If you want to blame me for what I've become,

You should give me credit for what I was."

These are slim pickings, and of course there have been various attempts to deduce more. Critics who are supercilious about such attempts should remember what Phaedrus said in the second fable of his fourth book:

But even then I'd like you to look

Closely and carefully at these light-weight confections:

They conceal a lot of useful lessons.

They are not always exactly what they seem:

Outward appearances are often deceptive,

And few are favored with a fine enough sense

To discover what the artist has concealed in a corner.

The most ambitious reconstruction of Phaedrus' life and career has been made by an Italian scholar, Attilio de Lorenzi. He traces his whole life, from exposure by his mother at birth (see the strangely powerful fable "The Dog and the Lamb," 3, 15) at the door of a highly educated poet and teacher of Greek; his upbringing in the house of this cultivated man; his attachment to the retinue of $L$. Calpurnius Piso Frugi, who was given the task of settling disturbances in Thrace in the period 13-11 B.C.; his transfer, after Piso's return to Rome, to the house of Augustus as tutor to his grandson and joint heir, Lucius; his informal manumission;* his further transfer to the staff of $\mathrm{Ti}$ berius' villa at Cape Misenum near Naples, where he spent the rest of his life; his condemnation by Sejanus; and his eventual rehabilitation

\footnotetext{
* There were two levels of manumission, formal and informal. The formal kind involved a ceremony before a magistrate and conferred almost complete civil rights. The informal kind was effected by a statement of freedom by the master among friends, or a symbolic slap, or an invitation to sit at dinner with him. It did not confer full civil rights; e.g., it did not provide the freedom to start a business.
} 
after Sejanus' death in A.D. 31. It is all done with constant reference to the history and mores of the times and with penetrating use of hints from the fables. No summary could do justice to the learning and ingenuity of this brilliant tour de force. However, intriguing as it is, very little of it unfortunately can be considered factual. What is solidly established is that by the time Phaedrus published his first book of fables he was a mature, assured, and accomplished artist, with a clear consciousness of his scope and his limitations. The first two fables, "The Wolf and the Lamb" and "The Frogs Ask for a King," are as concentrated, incisive, and effective as any that he wrote.

Phaedrus' surviving work consists of five books of fables (fabellac) based on the fables of Aesop, the traditional Greek inventor of the genre. There are thirty extra fables and three addresses to the reader in the so-called Perotti's Appendix, ${ }^{*}$ whose quality is uneven and subject matter very varied but which are considered genuine and are included in the text of Perry, and in these translations. The five books are of unequal length, which is one reason for thinking that the collection as we have it is incomplete. They contain 31, 8, 19, 26 and 10 fables, respectively, with a prologue for each and epilogues for three. By no means all are animal fables: only 59 out of a total of 94 ( 75 out of 126, with Perotti's Appendix included). ${ }^{\dagger}$ The intermediary whom Phaedrus is thought to have used as the source for his work was the celebrated Athenian orator and statesman Demetrius of Phalerum, the contemporary and friend of the poet Menander who compiled, in prose, in the fourth century в.c., the only known collection before Phaedrus of Aesop's fables. ${ }^{\ddagger}$

\section{Phaedrus, Aesop, and the Problem of Folklore}

Phaedrus is careful to tell us that his work is by no means mere imitation. In the first place, he has cast the fables in verse form:

\footnotetext{
* These were transcribed by the fifteenth-century scholar Niccoló Perotti from a manuscript of Phaedrus now lost.

${ }^{\dagger}$ For contents of the fables, see below.

* The collection has not survived, but it is recorded by Diogenes Laertius $(5,80)$, author of a compendium of the lives and writings of the philosophers in the third century A.D.
} 
Aesop is the author, the original inventor

Of the fables that follow, which I have refined

In a form of verse.

(1, Prologue, 1-3)

And then he develops the theme of independence much more fully in a later prologue:

Since, then, Particulo, you're partial to fables

(Which I call Aesopic, not actually Aesop's,

Since I've made more than the few he fathered,

Following his form, but with modern content),

You can now read the following, my fourth volume,

(4, Prologue, 14-18)

Phaedrus, then, thought that Aesop's fables had been invented and written by Aesop: he even tells us why, in the prologue to Book 3:

Slaves are exposed to incessant hazards.

Unable openly to express what he wanted,

One of them [Aesop] projected his personal opinions

Into fictional fables and found shelter

From carping critics in comic inventions.

This simple view of things, of course, was too good to last. Apart from the fact that Aesop was a semilegendary figure, a whole mass of conflicting theory has grown up in the area of myth and folklore, so much so in the case of fables that one critic has written: ". . . there is an 'Aesopic' just as there is a 'Homeric' Question." The question devolves from the same set of difficulties that puzzle students of myths and fairy tales. Iona and Peter Opie, for example, write: "Yet he [the student of fairy tales] finds himself faced by the astonishing fact that a body of tales have been found to be not merely ancient but to be traditional in a variety of countries and cultures, and that versions of a story told in widely separated parts of the earth will sometimes not merely bear resemblance, but possess actual points of detail in common."*

\footnotetext{
* Iona and Peter Opie, The Classic Fairy Tales, p. 21.
} 
And Michael Grant, speaking of mythology: "Everyone who compares the Greek and Roman mythologies with those of other cultures throughout the various countries of the world, and throughout the successive periods of history, will be amazed, indeed staggered, by the frequency with which the same stories recur, in closely similar or identical form, in a vast number of different lands, times and contexts."*

And J. W. Duff on Phaedrus: "On the one hand, the well-springs lay far deeper in primeval Aryan tales than Phaedrus could have dreamed, and on the other hand the fables which he asumed to be by Aesop consisted largely of accretions subsequent to Aesop's time. The primitive beast story, so widespread an element in folklore, becomes literary when it is shaped either to satiric or moral purpose. Some such shaping of the beast fable lies at the root of the renown of the Samian slave, the actual 'Aisopos,' who flourished in the middle of the sixth century B.C. ..."”

In very broad and oversimplified terms, the explanations offered for this phenomenon have been either psychological (that certain ideas and experiences are common and are likely to emerge anywhere at certain stages of development), morphological (that certain very general patterns of the structure of narrative are bound. to recur), or diffusionist (that, improbable as it may sometimes seem, there is in fact some conduit of transmission between two or more similar, or even identical, but widely separated stories). Needless to say, no one of these theories alone has commanded general acceptance. ${ }^{\ddagger}$

\section{The Fables}

To return to a more factual level, to the fables themselves as we have them and to what they contain and imply. Phaedrus' fables are

\footnotetext{
* Michael Grant and John Hazel, Who's Who in Classical Mythology, p. 8.

${ }^{\dagger}$ J. Wight Duff, ed. A. M. Duff, A Literary History of Rome in the Silver Age, p. 110.

₹ Anyone interested in pursuing this question in detail could usefully consult two learned articles on the duplication of the Phaedrus fable, Perotti's Appendix 16, "The Two Suitors": J. G. W. Henderson, "The Homing Instinct: A Folklore Theme in Phaedrus, App. Perott. 16 Perry/14 Postgate," Proceedings of the Cambridge Philological Society, new series 23 (1977): 17-31, and T. C. W. Stinton, "Phaedrus and Folklore: An
} 
an amalgam of diverse elements. The great majority have in common a moral lesson, stated or implicit, namely, the animal fables and the overtly moral anecdotes. Besides these there are historical anecdotes, "King Demetrius and the Poet Menander" $(5,1)$; short stories, "The Widow and the Soldier"* (Perotti's Appendix 15); proverbs and sayings, "The Mountain in Labor" $(4,23)$; comic episodes, "The Butcher and the Monkey" (3, 4); curious facets of the behavior of animals, "The Hungry Bear" (Perotti's Appendix 22); and folk wisdom, "Aesop and the Farmer" $(3,3)$. And apart from their specific purposes, the fables shed incidental light on all sorts of interesting facets of Roman and Greek life: the status and level of expertise of doctors, women's attitude to childbearing, the cleverness and fair-mindedness of Augustus, pictures on tavern walls, variety acts in the theatre, and much else of random interest.

Phaedrus' attitude to life is one of dignified and humorous pessimism. There are the strong and there are the weak, and when it comes to a contest between the two, the stronger nearly always wins. The lamb, with justice and reason on his side, gets eaten by the wolf $(1,1)$; the cow, the she-goat, and the sheep imagine that they are equal partners with the lion, but, again in spite of justice and reason, when it comes to dividing up the spoils, the lion appropriates the whole lot $(1,5)$; the doves were stupid to put themselves under the protection of the kite $(1,31)$. And it is useless for the humble to protest. On the contrary, protesting may well bring a worse condition than the present one-as the frogs found when they asked for a more effective king than the log, and got sent a serpent $(1,2)$. And it was foolish of the crane to expect payment for removing a bone from the wolf's throat-it was payment enough that she was allowed to withdraw her head from his jaws $(1,8)$.

There is, however, a certain compensation for poverty: it offers no temptation to predators. The moral of "The Two Mules and the Robbers" is that poverty is safe and wealth is exposed to constant danger $(2,7)$. And there is one precious thing more important than all the

Old Problem Restated," Classical Quarterly, new series 29 (1979): 432-435. This latter article in particular is not only penetrating but also highly entertaining.

* This macabre story reappears as "The Widow of Ephesus" in Petronius' Satyricon, 111-112. 
power and wealth in the world: freedom, as the wolf was clever enough to see when tempted by the dog to submit himself to a master $(3,7)$ and as the horse found when, in his attempt to get his revenge on the wild boar, he found himself subjected to a man $(4,4)$. Occasionally, the weak even have the satisfaction of seeing the strong paid out. The defrauded sheep has the pleasure of coming upon the wolf who gave false testimony against him lying dead in a pit $(1,17)$; the stork gets his own back on the fox by serving him, in return for his malicious joke, food that he cannot eat $(1,26)$; and the panther has his revenge on the humans who gratuitously maltreated him $(3,2)$.

Beyond all questions of power and weakness are lessons for everyone, the high and the lowly. Presumption and conceit are often punished. The jackdaw is banished by his peers for dressing himself up in the peacock's feathers $(1,3)$; the crow loses his cheese to the fox from vanity $(1,13)$; the frog bursts trying to make himself as big as the ox $(1,24) ;$ the fly makes himself ridiculous by his empty threats to the mule $(3,6)$; and the peacock is reproved by Juno for claiming more than has been allotted to him $(3,18)$.

\section{Reputation}

Phaedrus is usually classed in the literary histories among the "minor poets," but tribute has always been paid to his artful brevity (of which he himself was very proud, as we have seen above), his humor, and his simple and appropriate style and diction. He has been popular ever since his own day and has only been overshadowed in his chosen field in some respects by La Fontaine, who covered part of the same ground and acknowledged Phaedrus as one of his sources. Indeed, La Fontaine wrote in his preface to his fables:

On ne trouvera pas ici l'élégance ni l'extrême brièveté qui rendent Phèdre recommendable: ce sont qualités au-dessus de ma portée. Comme il m'était impossible de l'imiter en cela, j'ai cru qu'il fallait en recompense égayer l'ouvrage plus qu'il n'a fait. Non que je le blâme d'en être demeuré dans ces termes; la langue latine n'en demandait pas davantage; et si l'on y veut prendre garde, on reconnaîtra dans cet auteur le vrai génie de Térence. 
Neither the elegance nor the extreme brevity that are so appealing in Phaedrus will be found here: those are qualities beyond my scope. Since it was impossible for me to imitate him in that respect, I thought that I should make up for it by enlivening the work more than he had done. Not that I find fault with him for having stayed within those limits; the Latin language required no more; and if you pay close attention, you will find in this author the true genius of Terence.

Generous words. And all the more so, in that it is precisely because of his ability to "enliven" (égayer), which includes the delicate characterization of his creatures and the easy appropriateness of his rhyming, that La Fontaine is so much admired.

Phaedrus had another claim to fame in his day: to have been the first to adapt a whole Greek genre to Latin literature. In the Roman literary context this was an important contribution. Latin writers felt overshadowed by the vast achievement of Greece in so many areas of literature, and any writer who pioneered in introducing one of them to the Roman public was proud of his feat and was entitled to consider that he had done something original. Thus Virgil's model for the Eclogues was the Sicilian Greek Theocritus (cf. Eclogue 4, 1); for the Georgics, Hesiod (cf. Georgics, 2, 176), and for his epic poem, Homer. In fact the only genre in which Latin writing did not start from a Greek model was satire: hence the celebrated claim by the rhetorician and critic Quintilian, "Satire is entirely ours."

Thus, the position of an innovator like Phaedrus was ambiguous. He was proud of introducing something that was admittedly not entirely his; and he was equally proud of having to some extent transcended his model and made the material his own. He writes in the prologue to Book 2:

When I elaborate the incidents of a story, If it catches the ear and adds color to the content, My efforts should be appreciated on their own merits And not go unnoticed under the name of Aesop.

Of course, I shall be careful to conserve his spirit; But if I indulge in inventions of my own, 
To divert my public by the pleasure of variety, I count on you, Reader, for your kind indulgence, And may conciseness compensate for the license you allow me.

And later in the same book:

Forestalled by another from being first in the field, I have labored long at the little that was left me, Namely to ensure that he should not be unique; And not out of envy, but emulation. And if my efforts find favor with Rome, She'll have one more weapon to wield in the challenge Against Greece; and if green-eyed Jealousy pleases to disparage my pains, She will not steal from me my self-esteem.

$(2,9,5-13)$

\section{Meter of Translation}

Phaedrus wrote in the meter of Iambic Senarii, that is, lines of six iambic feet, with various resolutions and variations. This was one of the standard meters used for dialogue and soliloquy in Greek and Roman drama and, as such, was well suited to Phaedrus' style and purpose. Unfortunately, in English, whereas the five-foot iambic line is a natural verse rhythm for English speech, the six-foot iambic line has never taken hold, and for some mysterious psychometrical reason it reads awkwardly. I have chosen to express Phaedrus' fluent and colloquial rhythms in a modified version of Anglo-Saxon and Middle English alliterative verse, as exemplified by Piers Plowman and revived by W. H. Auden (successfully, as I think) in The Age of Anxiety. The meter is simple. It consists of unrhymed lines of no fixed number of syllables, but with four stresses in each line, each line being divided into two halves with two stresses each. In its pure form, at least two, usually three, and occasionally four of the stressed words are alliterated, the alliteration being set by the first stressed word of the second half, that is, the third beat. Thus, Piers Plowman begins: 
In a summer 'season when 'oft was the sun

and The Age of Anxiety:

My deuce, my double, my dear ímage

And my version of Phaedrus 1, 1:

To the selfsame stream, to slake their thirst

I have allowed myself considerable latitude in the matter of alliteration, preferring to depart from strict orthodoxy rather than from the required sense. I have not always based the alliteration on the third stress; I have used assonance of vowels sometimes in place of alliteration of consonants; I have sometimes used two different alliterations in one line; and there are some lines with little or no alliteration, but in that case usually referring alliteratively to the line before or after. Given this freedom, it is a natural meter to write, congenial to English speech, and, I think, easy to read. I hope that the reader finds it so.

\section{Christopher Smart's Translation}

The last translation of Phaedrus into English verse was made by Christopher Smart and was published in 1764. Smart had been confined in Potter's madhouse in Bethnal Green for the four years between 1759 and early 1763. Soon after his release he published a volume of poems, A Song to David, and a translation of the Psalms into

\footnotetext{
* It is accessible in the Bohn series of classical translations in the volume entitled "The Comedies of Terence and the Fables of Phaedrus, literally translated into English prose with notes, by Henry Thomas Riley, B.A., to which is added A Metrical Translation of Phaedrus by Christopher Smart, A.M. London, Bell and Daldy, 1872." There is also a version by Sir Brooke Boothby, Bart (Edinburgh: Archibald Constable and Co., 1809) concealed under the title Fables and Satires. Besides Phaedrus, it contains fables from various other sources, including some of La Fontaine's, and four satires of his own. It is similar in style and meter to Smart's translations and is often neat and trenchant in expression, but it sacrifices so much to brevity and the demands of rhyme as to be closer to a paraphrase than a translation.
} 
rhyming verse. He had also been writing the extraordinary Jubilate Agno, although this was not published in his lifetime, or indeed until 1939. This output is proof of the limited nature of his madness. He was afflicted (if that is the word) with a religious mania that manifested itself in the constant desire to pray and, when in public places, to draw others into prayer with him; but it is clear that his intellect was not affected. In December 1764 he published his translation of Phaedrus, and it seems probable that he had been working on that also during his time in the madhouse.

Smart's translation is in eight-syllable rhyming couplets. It was addressed primarily to a young audience (and a Latin-learning one at that) and was dedicated to the sons of some patrons of his. In an advertisement for it he wrote: "Upon the whole, the young reader by this explanatory version and parsing index will get the drift of the author's meaning, learn his syntax, and make a better progress in the tongue than he would by a mere prose translation, which is rather too great a help."* Smart was a good scholar. He had been a fellow of Pembroke College, Cambridge, and was proud of his reputation as a classicist. The review in the Critical Review concluded: "Phaedrus is remarkably concise; this version is diffuse. In some places the translator has embellished the author's narration, and given an ingenious turn to a simple expression: but he has not refined his language with a proper degree of nicety and care; many of his verses are encumbered with feeble expletives and unnecessary words."

In general, this is a reasonable criticism. But in fairness to Smart it should be said, first, that it is impossible in an extended translation to match the conciseness of Latin in English owing to the difference in grammar and syntax of the two languages; second, that the intrusion of unnecessary words is a feature endemic to rhymed translation, a form the fashion of the eighteenth century almost dictated (Smart's rhyming, at which he had had long practice in his work on the Psalms, quite apart from his own poems, was admirably versatile and deft); and third, that the famous conciseness of Phaedrus is not always a virtue, but could sometimes rather be called sparseness.

\footnotetext{
* I am indebted for this and other information about Smart to Christopher Smart, Scholar of the University by Arthur Sherbo.
} 
Here is a good specimen of Smart's manner in a familiar fable (Phaedrus 4, 3):

The Fox and the Grapes

An hungry fox with fierce attack

Sprang on a vine, but tumbled back,

Nor could attain the point in view,

So near the sky the bunches grew.

5 As he went off, "They're scurvy stuff,"

Says he, "and not half ripe enough-

And I've more reverence for my tripes

Than to torment them with the gripes."

For those this tale is very pat

10 Who lessen what they can't come at.

Phaedrus' original displays his conciseness at its best, and Smart, with a few omissions, comes close to it: only the seventh and eighth lines could be regarded as unduly expanded. 
THIS PAGE INTENTIONALLY LEFT BLANK 